\title{
Targeted mutagenesis of the murine IRP1 and IRP2 genes reveals context-dependent RNA processing differences in vivo
}

\author{
BRUNO GALY, DUNJA FERRING, MONIKA BENESOVA, VLADIMIR BENES, and MATTHIAS W. HENTZE \\ European Molecular Biology Laboratory, 69117 Heidelberg, Germany
}

\begin{abstract}
We report the targeted mutagenesis of the murine iron regulatory protein (IRP)-1 and IRP2 genes, respectively, with a classical gene trap construct. Insertion of the targeting cassette into the second intron of either gene by homologous recombination interrupts their open reading frames near the $\mathbf{N}$ termini. Mice that are homozygous for the correctly modified IRP1 or IRP2 alleles, respectively, display a strong reduction $\left(90 \%, I R P 1^{-/-}\right)$or nondetectable levels $\left(I R P 2^{-/-}\right)$of the targeted proteins. Interestingly, the pre-mRNAs transcribed from the identical targeting cassettes are processed differently within the two different contexts. Detailed analysis of the respective products identifies the choice of alternative splice and 3 ' end processing sites in the same tissues in vivo. We discuss the implications for the understanding of RNA processing and for targeting strategies for functional genomics in the mouse.
\end{abstract}

Keywords: alternative splicing; mRNA processing; gene trap; iron metabolism, NMD

\section{INTRODUCTION}

Manipulation of the mouse genome for in vivo exploration of gene functions requires reliable and predictable strategies to mutagenize a given locus. Gene trap strategies have proven to be powerful tools not only to tag and identify new genes and to study their expression in vivo, but also to explore their in vivo function, because gene trap constructs commonly cause disruption of the targeted gene (Skarnes et al. 1992; Zambrowicz and Friedrich 1998; Stanford et al. 2001). Different gene trap vectors have been used in largescale insertional mutagenesis approaches to generate thousands of embryonic stem (ES) cell clones for mice deficient in the trapped gene (e.g., see http://tikus.gsf.de; Bonaldo et al. 1998; Wiles et al. 2000). In some cases, no obvious phenotype was observed in homozygous mutant mice (Stoykova et al. 1998; Voss et al. 1998a,b), possibly reflecting functional redundancy. In addition, splicing abnormalities affecting the gene trap construct have been described,

Reprint requests to: Matthias W. Hentze, European Molecular Biology Laboratory, Meyerhofstrasse 1, 69117 Heidelberg, Germany; e-mail: hentze@embl.de; fax: 496221387518.

Article and publication are at http://www.rnajournal.org/cgi/doi/ 10.1261/rna.7220704. which could account for some residual expression of wildtype mRNAs from targeted alleles (Voss et al. 1998a, 2003; Salminen et al. 2000). Although hypomorphic alleles can cause severe phenotypes (e.g., Serafini et al. 1996; GonzalezBillault et al. 2000; Salminen et al. 2000; Voss et al. 2003), residual expression of the targeted gene may also prevent phenotypic manifestations. It is therefore important to fully understand the effect of gene-targeting cassettes on the targeted gene.

Recent work revealed the close physical, temporal, and functional linkage and interdependence between transcription and mRNA maturation (Orphanides and Reinberg 2002). Much of our understanding of pre-mRNA splicing and $3^{\prime}$ end processing is based on cell-free assays, often using minimized model constructs removed from their natural context. Here, we compare the processing of the same gene-targeting cassette inserted into different, yet related, loci of the mouse genome. A gene trap IRES- $\beta$ Geo cassette (Chowdhury et al. 1997) was introduced into the second intron of the iron regulatory protein IRP1 and IRP2 genes by homologous recombination in embryonic stem (ES) cells. IRP1 and IRP2 are RNA-binding factors that orchestrate the coordinated regulation of translation or turnover of mRNAs bearing iron-response elements (IREs) 
in their untranslated regions and encoding proteins of iron homeostasis (Cairo and Pietrangelo 2000). Thorough analysis of the expression and the processing of the mRNAs encoded by the targeted IRP1 and IRP2 alleles in mouse tissues revealed unexpected features of the IRES- $\beta$ Geo gene trap construct, the behavior of which is profoundly affected by the locus of integration. These results have direct implications for gene trap strategies for functional genomics in the mouse. They also highlight unexpected complexities of RNA processing in vivo.

\section{RESULTS AND DISCUSSION}

\section{Targeted mutagenesis of the IRP1 or IRP2 loci in the mouse}

To target the IRP1 or IRP2 gene, we opted for a gene trap vector (Fig. 1) that has been used in a large-scale mutagenesis project of the mouse genome (Wiles et al. 2000) as well as in other targeted mutagenesis studies (e.g., Herrmann et al. 2003). The cassette consists of a splice acceptor (SA) from the engrailed-2 (eng-2) gene followed by the encephalomyocarditis virus (EMCV) internal ribosome entry site (IRES) that directs the translation of a fusion protein with $\beta$-galactosidase and neomycin-resistance activities ( $\beta \mathrm{Geo})$, and ends with the simian virus 40 late poly(A) signal. This construct allows both G418 selection of transfected ES cells and in situ detection of $\beta$-galactosidase activity to monitor the expression of the gene of interest in the animal. The transcription of this promoterless construct depends on the promoter of the endogenous gene, thereby favoring the selection of homologous recombination versus random integration events. Splicing from the upstream splice donor of the targeted gene to the eng-2 splice acceptor creates a chimeric bicistronic mRNA that terminates prematurely

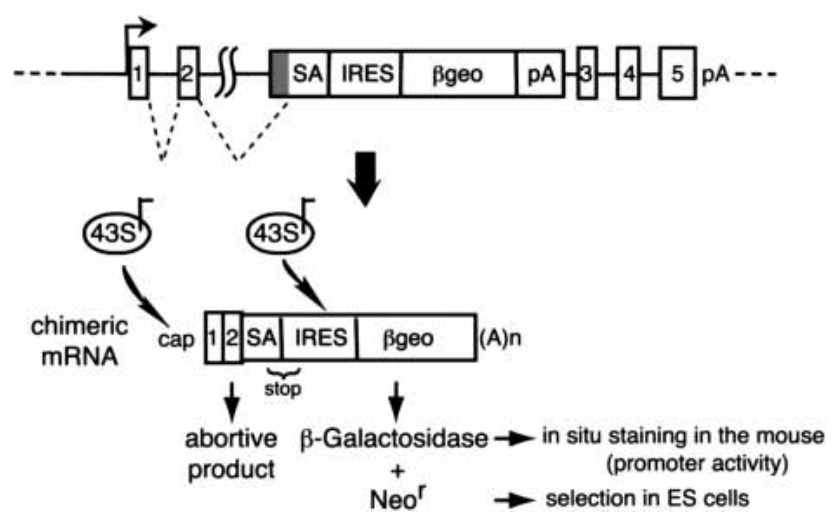

FIGURE 1. Schematic representation of the $\beta$ Geo gene trap construct. The polyadenylation signals $(\mathrm{pA})$ of the cassette and of the targeted gene are indicated. The IRES (Internal Ribosome Entry Site) drives the translation of the $\beta \mathrm{Geo}$ cistron. following the SV40 poly(A) signal as illustrated in Figure 1. The first cistron consists of the first two exons of the IRP genes fused to a part of the eng-2 exon and encodes abortive products. Therefore, insertion of this cassette is expected to abrogate the expression of functional IRP1 and IRP2 proteins, respectively, resulting in a complete and constitutive knockout. To enable the conditional inactivation of the IRP genes, the $\beta$ Geo construct is flanked with frt sites for excision with the Flp recombinase (Dymecki 1996), and the frame-shifting exon (exon 3 in both IRP1 and IRP2 loci) is sandwiched between loxP sites for removal by Cre recombinase (Fig. 2A; Nagy 2000). Figure 2, B and C, depicts a Southern-blot and PCR analysis of the DNA of wild-type and mutant mice to confirm the correct insertion of the targeting cassette. Excision of the selection cassette by Flp recombination generates a floxed allele and restores normal IRP expression that can subsequently be abolished by Cre recombinase-mediated excision of exon 3 (data not shown). All the experiments described below were performed with mice carrying mutant IRP alleles in which the gene trap construct was present.

\section{Effect of the gene trap construct on IRP1 and IRP2 expression}

We next analyzed the expression of the targeted IRP1 and IRP2 alleles at the RNA and protein levels in the brain, duodenum, kidney, spleen, and liver of 5-wk-old mice. We present the data obtained from liver samples (Fig. 3), but similar results were obtained from all five organs (data not shown). As expected, IRP1 mRNA is not detected in IRP $1^{-1-}$ mice when assessed by Northern blotting. In contrast, IRP2 mRNA levels in IRP2 ${ }^{-/-}$mice are surprisingly unchanged (Fig. 3A). A similar result has been reported for a related gene trap construct inserted into the MAP4 locus, where a combination of read-through transcription and splicing across the gene trap cassette restored mRNA expression (Voss et al. 1998b). We then analyzed protein expression by Western blot in liver extracts of the same animals. A strong reduction in IRP1 is observed in the IRP1 $1^{-/-}$ mice, but a faint IRP1 signal is detectable on longer exposures (Fig. 3B, left panels). A serial dilution analysis revealed that the IRP1 signal in the mutant mice accounts for $\sim 5 \%$ of wild-type levels (data not shown). These results were confirmed by a gel retardation assay for IRE-binding activity using the ferritin-H IRE as a probe (Fig. 3C, left panel). The fact that no IRP1 mRNA could be detected in spite of the presence of a residual amount of protein is likely due to the limited sensitivity of Northern blotting (see RT-PCR analysis below and Fig. 4). In sharp contrast to the unchanged IRP2 mRNA level in IRP2 $2^{-/-}$mice, IRP2 protein expression is undetectable both by Western blot and bandshift experiments (Fig. 3B,C, right panels). Note that IRP2 is more difficult to detect than IRP1, and we cannot exclude 
A

$$
\begin{array}{ll}
\text { loxP site } & \text { El: EcoRI } \\
\text { Ofrt site } & \text { EV: EcoRV } \\
& \text { S: Sacl }
\end{array}
$$
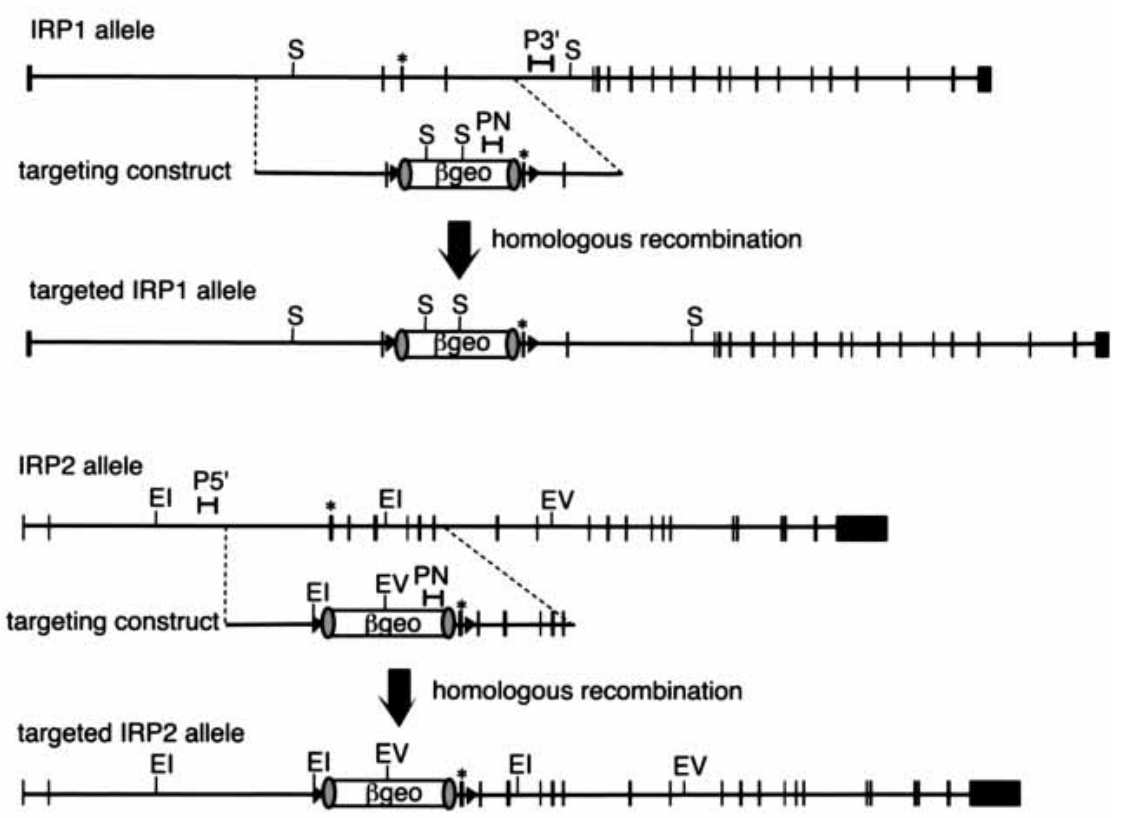

B
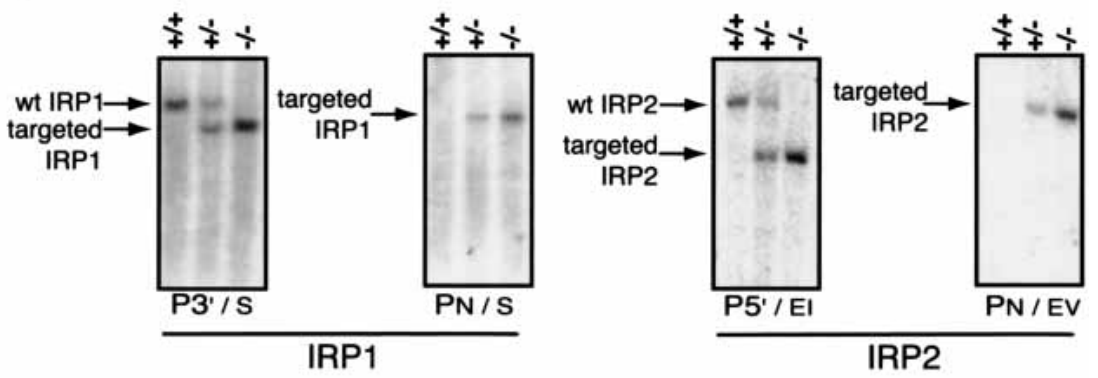

C

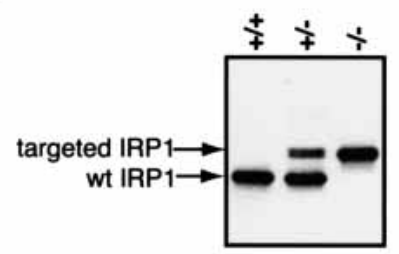

IRP1

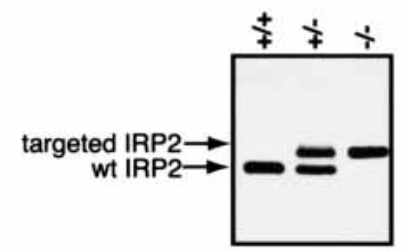

IRP2
FIGURE 2. Generation of conditional IRP1 and IRP2 alleles in the mouse. (A) Schematic representation of the wild-type and targeted IRP1 (upper part) or IRP2 (lower part) loci and of the targeting constructs. The IRP1 and IRP2 genes consist of 21 and 22 exons, respectively. The floxed exon is marked with an asterisk. Restriction sites are indicated. The IRP1 3' external probe (P3'), the IRP2 $5^{\prime}$ external probe (P5'), and the common Neo probe (PN) are shown. (B) The targeted IRP1 (left panels) and IRP2 (right panels) loci were analyzed by Southern blotting using the restriction enzymes and probes indicated below the panels. The genotype is indicated above each lane. The IRP1 P3' probe reveals a 15.8-kb vs. a 12.7-kb fragment, and the IRP2 P5' probe reveals a $13.2-\mathrm{kb}$ vs. a 9.4-kb fragment corresponding to the wild-type or the targeted alleles, respectively. A Neo probe shows the expected $15.8-\mathrm{kb}$ and $16.8-\mathrm{kb}$ fragments in mice bearing IRP1 or IRP2 targeted alleles. (C) PCR detection of downstream loxP sites. The primer pairs A51/A52 and B37/B38 (Table 1) were used to amplify the region of the IRP1 or IRP2 genes into which the downstream loxP site was inserted. They generate fragments of 212 and $182 \mathrm{nt}$ from the wild-type IRP1 or IRP2 alleles, respectively. Fragments of 264 and $225 \mathrm{nt}$ were obtained from the targeted IRPI or IRP2 alleles, respectively. This PCR procedure was used for genotyping. that a very small amount of IRP2 could be produced. Thus, we find residual IRP1 protein expression in the context of negative Northern-blotting data, whereas near-wild-type IRP2 mRNA levels in IRP2 ${ }^{-/-}$mice fail to yield detectable protein. This discrepancy between RNA and protein data suggests that the IRP2 mRNA detected in $\mathrm{IRP}^{-/-}$mice is abnormal. Furthermore, the presence of residual amounts of IRP1 in mice carrying two IRP1 mutant alleles indicates that the gene trap construct is leaky, as has been seen in isolated cases before (Gonzalez-Billault et al. 2000; Salminen et al. 2000; PiresdaSilva et al. 2001). Clearly, these results highlight the necessity of a careful and thorough analysis of targeted alleles at the DNA, mRNA, and protein level.

Similar to previous findings (LaVaute et al. 2001), IRP2 ${ }^{-/-}$mice are viable and fertile, and newborn mice do not display any gross abnormalities, showing that IRP2 is dispensable for normal development (B. Galy, D. Ferring, B. Minana, M. Muckenthaler, M.G. Jansen, K. Schuemann, and M.W. Hentze, in prep.). In contrast, insertion of the $\beta \mathrm{Geo}$ gene trap construct into the IRP1 gene leads to a partially penetrant embryonic lethality in homozygous animals. However, when the IRP1 mice were crossed with cre transgenic animals to derive a line carrying a null IRP1 allele (due to the deletion of exon 3) but lacking the $\beta$ Geo cassette (cf. Fig. 2A), the embryonic lethality phenotype was abrogated (B. Galy, D. Ferring, M. Sanchez, and M.W. Hentze, in prep.). These data show that the $\beta$ Geo construct is toxic when inserted into the second intron of the IRP1 gene and that IRP1 deficiency per se is not responsible for embryonic developmental defects. These data are consistent with findings reported recently for a different $\mathrm{IRP1}^{-/-}$strain (Meyron-Holtz et al. 2004). Detailed phenotypic analyses of the IRP1- and IRP2-deficient mice will be described elsewhere, and the mechanisms underlying the embryonic lethality remain to be elucidated. This lethality could potentially be explained by decreased expression of a hypothetical intron-en- 


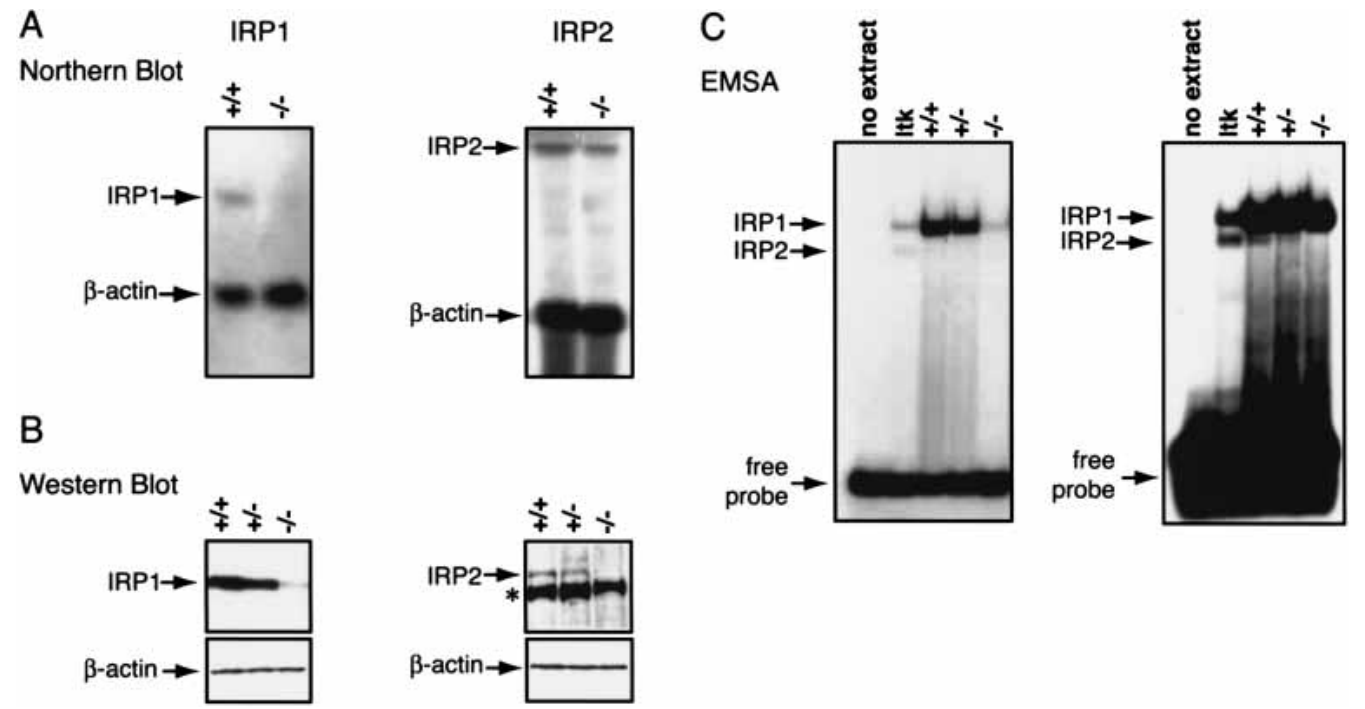

FIGURE 3. IRP expression in the liver of 5-wk-old mice with targeted IRP1 (left panels) or IRP2 (right panels) alleles. (A) Analysis of IRP mRNA expression. For this, $10 \mu \mathrm{g}$ of total RNA (IRP1) and $5 \mu \mathrm{g}$ of poly(A) ${ }^{+}$RNA (IRP2) were subjected to Northern-blot analysis using an IRP1 or an IRP2 probe obtained by PCR amplification of cDNAs from wild-type mice with the primers P1d/P1e or P2a/P2c, respectively (Table 1). The IRP probes were cohybridized with a $\beta$-actin control probe and revealed the expected 2000-nt $\beta$-actin mRNA and the 4000-nt IRP1 or 7400-nt IRP2 mRNAs. (B) Analysis of IRP expression. For this, $20 \mu \mathrm{g}$ of protein extract was loaded per lane and subjected to Western-blot analysis. The specific IRP2 signal is indicated with an arrow, a cross-reactive band by ${ }^{*}$. (C) Analysis of IRE-binding activity. Cytoplasmic extracts were used for EMSA using a human ferritin-H IRE probe. A mouse ltk fibroblast extract (ltk) was used as a positive control. The autoradiogram was overexposed to visualize the IRP2/IRE complex in IRP2 ${ }^{+-}$tissues. The genotype of the corresponding mice is indicated above each lane.

coded RNA located downstream from the insertion site of the $\beta$ Geo gene trap construct. However, searching of microRNA and intron-encoded RNA databases for IRP1 genomic sequences has not yet identified such a candidate RNA.

\section{Processing pathways of the pre-mRNAs encoded by the targeted IRP1 and IRP2 genes}

To determine the molecular basis of the unexpected discrepancies between mRNA and protein expression in IRP $1^{-/-}$and IRP2 ${ }^{-/-}$mice, cDNA was generated by reverse transcription of liver RNA and used for PCR amplification (Fig. 4B). The expected chimeric IRP1 and IRP2 mRNAs can be detected using a forward primer corresponding to exon 1 and a reverse primer matching the $\beta$ Geo cassette 123 nt downstream from the SA in $+/-$ and $-/-$ mice but not in their wild-type counterparts (Fig. 4A, p1a/pR and p2a/pR). Note that this PCR was performed under saturating conditions and therefore does not show the relative amounts of the chimeric mRNA in the different lanes. Confirming the Northern-blot data, we detect a strong reduction in IRP1, but no variation in IRP2 mRNA levels using primers corresponding to the first and the last exons (Fig. 4A, p1a/p1b and $\mathrm{p} 2 \mathrm{a} / \mathrm{p} 2 \mathrm{~b})$. These data show that the poly(A) signal of the gene trap cassette is partially or totally ignored when it is inserted into the IRP1 versus the IRP2 gene, respectively. Note that the $6.9-\mathrm{kb}$ upstream and $0.1-\mathrm{kb}$ downstream sequences surrounding the affected poly(A) site are strictly identical in both IRP1 and IRP2 loci. Sequencing of the PCR products corresponding to the last $600 \mathrm{nt}$ of the $\beta \mathrm{Geo}$ cassette confirmed the integrity of the poly(A) site in both IRP1 and IRP2 mutant mice (data not shown).

Using a reverse primer closer to the $5^{\prime}$ end of the cDNA, two signals can be resolved from samples of IRP1 $1^{-1-}$ mice: a DNA fragment corresponding to the wild-type mRNA and a faint band (labeled ${ }^{\star}$ ) that is slightly larger (Fig. 4A, pla/p1c). In samples from IRP2 mutant mice, a similar additional band is amplified. However, in contrast to the IRP1 $1^{-/-}$case, it represents the only detectable signal (Fig. 4A, P2a/P2c). These results confirm the leakiness (partial or total) of the poly $(\mathrm{A})$ signal of the gene trap cassette. Sequencing of the PCR products reveals that the pre-mRNAs are alternatively spliced. The lower band corresponds to the wild-type IRP1 mRNA, showing that the eng-2 SA is skipped (Fig. 4B,C, event B) and accounting for the residual level of IRP1 in the $-/-$ mice. The upper band corresponds to an mRNA generated by proper joining of exon 2 with the SA of the cassette (Fig. 4B,C, situation $\mathrm{A}$ ) and the activation of a cryptic splice donor site located $115 \mathrm{nt}$ downstream, which splices to the splice acceptor of exon 3 (Fig. 4B,C, situation C). To distinguish the wild-type IRP2 cDNA from the cDNA with the 115-nt insertion, we used a primer spanning the IRP2 exon 2/exon 3 junction (Fig. $4 \mathrm{~B}$, primer $\mathrm{p} 2 \mathrm{~d})$. As shown in Figure $4 \mathrm{~A}$, no signal is detected in IRP2 ${ }^{-1-}$ mice with the $\mathrm{p} 2 \mathrm{~d} / \mathrm{p} 2 \mathrm{~b}$ primers, demonstrating that the SA of the $\beta$ Geo cassette is not skipped and that the mRNA arising from the splicing events $A+C$ (Fig. 4B,C) prevails in IRP2 mutant mice. The 115-nt insertion creates a frameshift with premature termination of translation within the third 
A

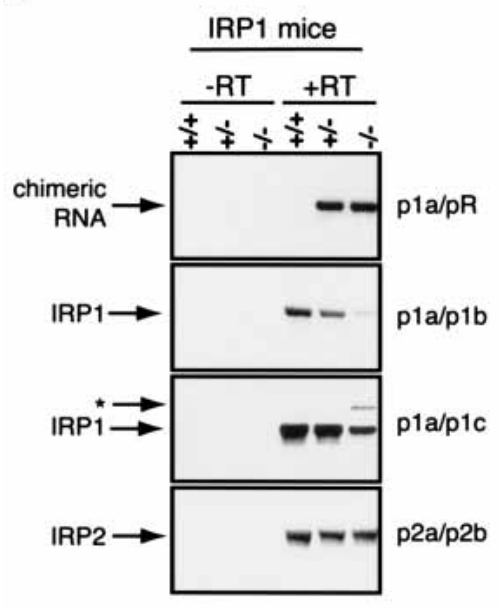

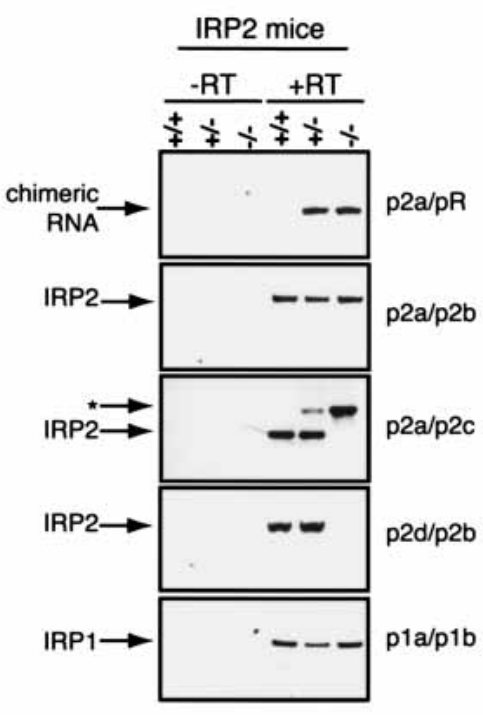

B

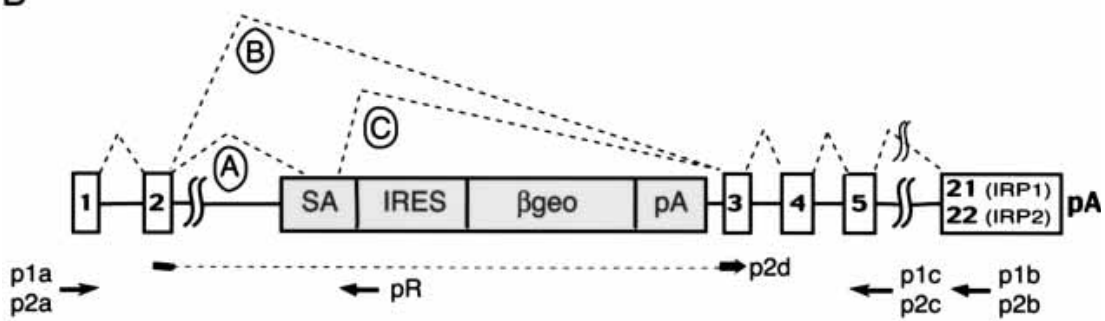

C

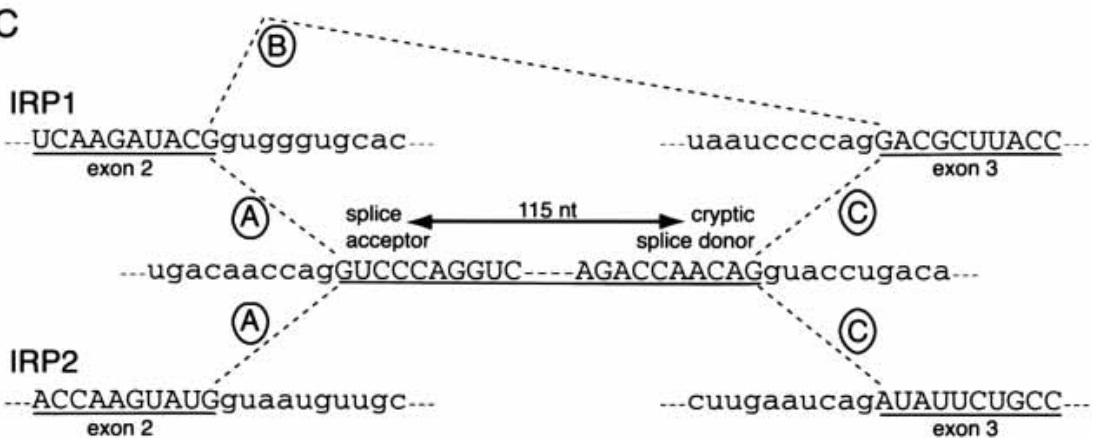

FIGURE 4. RT-PCR and CDNA sequencing analysis of the processing of the chimeric IRP- $\beta$ Geo mRNA in the liver of 5-wk-old mice with targeted IRP1 (left panels) or IRP2 (right panels) alleles. (A) RT-PCR analysis from total RNA. The primers used for PCR amplification are indicated on the right side of each panel and listed in Table 1. The genotype of the animals is indicated above each lane. In lanes labeled -RT, the reverse transcriptase was omitted to exclude contamination with DNA. Saturating PCR conditions were used with primers $\mathrm{pla} / \mathrm{pR}$ and $\mathrm{p} 2 \mathrm{a} / \mathrm{pR}$, and with primers $\mathrm{pla} / \mathrm{p} 1 \mathrm{c}$ to visualize the upper band $\left(^{*}\right)$ in the $\mathrm{IRP}^{-1-}$ mice. In all the other cases, the PCR was done under nonsaturating conditions. $(B)$ Schematic representation of the targeted allele and the splicing events revealed by the analysis in $A$. The positions of the primers used in $A$ are indicated. $(C)$ Splice site choices were precisely determined by DNA sequencing of RT-PCR amplification products. Exonic sequences are in capital letters and underlined. The middle sequence corresponds to the $\beta G e o$ cassette and the upper and bottom sequences to the IRP1 and IRP2 mRNAs, respectively.

IRP2 exon. Therefore, the resulting mRNA fails to encode functional IRP2 protein. Another important implication of the in vivo processing of the RNA precursors transcribed from the mutated IRP2 allele is that measurement of $\beta$-galactosidase activity may not accurately reflect the activity of the IRP2 promoter.

Perhaps the most revealing aspect of our observations is the apparent influence of a targeted genomic locus on the behavior of the gene trap cassette. What could be the causes of such unexpected long-range context dependence? In principle, determinants at the DNA/ chromatin level as well as the premRNA/RNP level could influence the accumulation of specific mature mRNA processing products in vivo. Thus, the steady-state pattern of accumulated mRNAs could be determined by different processing and/or stability of the mRNAs transcribed from the targeted alleles. The presence of a premature stop codon (PTC) in the IRP1 and IRP2 mRNAs with the 115-nt insertion is expected to trigger nonsense-mediated mRNA decay (NMD). It is possible that ineffective NMD of the aberrant IRP2 transcript is responsible for its accumulation to near-wild-type mRNA levels, whereas the similarly aberrant IRP1 transcript may undergo NMD more efficiently. Differences in the susceptibility of PTC-containing mRNAs have been reported (Romao et al. 2000; Danckwardt et al. 2002). On the other hand, differences in mRNA processing may account for the relative levels of the transcripts synthesized from the mutated IRP alleles. Examination of the different splice site sequences (Fig. 4C) does not reveal an explanation for why skipping of the eng-2 SA is more prevalent in the context of the IRP1 versus the IRP2 locus nor why the eng- 2 cryptic splice donor is selected very efficiently by the splicing machinery in the context of the IRP2 gene. Because the $1.7-\mathrm{kb}$ upstream and 5.4-kb downstream sequences surrounding the eng-2 SA are identical in both mutant IRP alleles, it is conceivable that long-range interactions influence the processing of the $\beta \mathrm{Geo}$ cassette. A clear difference between the two alleles is the distance between the respective second IRP exons and the eng-2 splice acceptor sites: $2.1 \mathrm{~kb}$ (IRP1) versus $17.3 \mathrm{~kb}$ (IRP2). The position of the $\beta$ Geo construct relative to cis-regulators of IRP pre- 
mRNA processing may affect splice site choices. Finally, differences in the chromatin context of the IRP genes may influence the composition of the pre-mRNA processing machinery and direct the gene trap construct through different processing pathways. Importantly, the processing differences of the IRP1 and IRP2 pre-mRNAs were not limited to the liver, because similar results were obtained from brain, spleen, duodenum, and kidney samples (data not shown). This suggests that these processing differences involve general or ubiquitous rather than tissue-specific processing factors/machineries.

Alternative pre-mRNA processing has been studied by comparing the expression of individual model genes in different temporal, developmental, or cell-type-specific situations. Here we compared the processing of the same genetic element within two loci in the same tissue and at the same developmental stage. Our results reveal unexpected complexities of the processing of a classical gene trap vector, and strongly support the importance of the genomic context and long-range interactions within the pre-mRNAs. Thorough analysis of the products synthesized from targeted alleles is critical to avoid misinterpretation of phenotypes, and will help to refine existing vectors for even more reliable engineering of the mouse genome.

\section{MATERIALS AND METHODS}

\section{Gene targeting and mice}

The plasmid carrying the $\beta$ Geo construct was a gift from F.A. Stewart (University of Dresden, Germany). For IRP1, an Sv129/ Ola genomic library (RZPD) was screened, and three overlapping clones, MPMGc121M08296Q2, MPMGc121J13748Q2, and MPMGc121C23410Q3, were obtained with probes corresponding, to the $5^{\prime}$, middle, and $3^{\prime}$ parts of the IRP1 mRNA, respectively. The sequence of the full Acol locus has been deposited (GenBank accession number AJ427344). A targeting construct with 5' and 3' homology arms of 7.9 and $6 \mathrm{~kb}$, respectively, was obtained by conventional cloning techniques. For IRP2, a 15-kb Sv129 genomic clone was kindly provided by B. Leibold (University of Utah, USA). The IRP2 targeting construct was generated by ET cloning (Zhang et al. 2000) and bears $5^{\prime}$ and $3^{\prime}$ homology arms of 5.5 and $6.1 \mathrm{~kb}$, respectively. Further details concerning these constructs are available at http://www.embl-heidelberg.de/ ExternalInfo/hentze/suppinfo.html.

E14 ES cells were electroporated with the targeting constructs and cultivated in the presence of G418 (Invitrogen). ES cell clones were analyzed by Southern blotting using ${ }^{32} \mathrm{P}$-labeled PCR probes obtained with the primer pairs $\mathrm{P} 5{ }^{\prime}-\mathrm{S} / \mathrm{P} 5-\mathrm{R}, \mathrm{P} 3^{\prime}-\mathrm{S} / \mathrm{P} 3^{\prime}-\mathrm{R}$ and $\mathrm{PN}$ S/PN-R (Table 1) for the $\mathrm{P}^{\prime}, \mathrm{P}^{\prime}$, and $\mathrm{PN}$ probes, respectively (Fig. 2). ES cell clones were injected into C57BL6/J embryos to obtain chimeras that were backcrossed to C57BL6/J mice to check for germ-line transmission of the mutated IRP alleles. The results presented in this study were obtained with mice on a mixed C57/ SV129 genetic background. Two IRP1 mutant lines derived from two independent ES cell clones have been analyzed. Animal care was in accordance with institutional guidelines.

\section{IRP protein analysis}

Flash-frozen tissues were homogenized in lysis buffer $(10 \mathrm{mM}$ Tris at pH 8, $150 \mathrm{mM} \mathrm{NaCl}, 1 \mathrm{mM}$ EDTA, 1\% NP-40, 0.1\% SDS for Western blot, or $25 \mathrm{mM}$ Tris at $\mathrm{pH} 7.4,40 \mathrm{mM} \mathrm{KCl}, 1 \%$ Triton X-100 for bandshift) complemented with $4 \mathrm{mg} / \mathrm{mL}$ PefablocSC, $0.1 \mathrm{mg} / \mathrm{mL}$ aprotinin, $20 \mu \mathrm{g} / \mathrm{mL}$ leupeptin, $40 \mu \mathrm{g} / \mathrm{mL}$ E64, $4 \mu \mathrm{g} / \mathrm{ml}$ pepstatin (all from Roche Diagnostic), and $10 \mathrm{mM}$ EDTA. Lysates were incubated for $30 \mathrm{~min}$ and debris was removed by repeated

TABLE 1. Sequence of the primers used

\begin{tabular}{|c|c|c|}
\hline Primer & Sequence $5^{\prime} \rightarrow 3^{\prime}$ & Comments \\
\hline $\mathrm{pR}$ & AGACTCTGGCGCСGСТGСТCTG & Bgeo construct, reverse \\
\hline p1a & TGCTCCGGGAACTGCACTGTGAGCG & IRP1, sense. exon 1 \\
\hline $\mathrm{p} 1 \mathrm{~b}$ & ACATCAGTGTCGAACCTCATCACG & IRP1, reverse, exon 21 \\
\hline p1c & АCTCCAGGTCTTGATTCTTCTG & IRP1, reverse, exon 5 \\
\hline p1d & GATTTGGGATTCCACGCATACAGC & IRP1, reverse, exon 16 \\
\hline p1e & TGCTCCGGGAACTGCACTGTGAGCG & IRP1, sense, exon 1 \\
\hline p2a & ATATGGTCTCCGGCGATGGACTC & IRP2, sense, exon 1 \\
\hline $\mathrm{p} 2 \mathrm{~b}$ & ATCACGСTGAACTCTTTTCСАGTGC & IRP2, reverse, exon 22 \\
\hline p2c & TTCAСТGССТСССТСАТАGС & IRP2, reverse, exon 5 \\
\hline $\mathrm{p} 2 \mathrm{~d}$ & GGCACCAAGTATGATATTCTGC & IRP2, sense, exon 2-exon 3 junction \\
\hline P5'-S & AАCTCСTTGTAGTGGGAATTGAACC & IRP1, sense, intron 1 \\
\hline$P 55^{\prime}-R$ & AGACTAGACTGGTCTTCTAAGCTTCAG & IRP1, reverse, intron 1 \\
\hline P3'-S & AAGTTGAGAAGTAAATATCCAG & IRP1, sense, intron 4 \\
\hline$P 3^{\prime}-R$ & TGAACССТGССТATCTGGTATCC & IRP1, reverse, intron 4 \\
\hline PN-S & TCAGAAGAACTCGTCAAGAAGGCG & ßgeo construct, sense, Neo cassette \\
\hline $\mathrm{PN}-\mathrm{R}$ & GCTTACATAAACAGTAATACAAGGGG & Bgeo construct, reverse, Neo cassette \\
\hline B37 & CCAGGAGATAAAAGGAAGGCAAGG & IRP1, sense, intron 3 \\
\hline B38 & TCTATCССTGAGGTCGGTAGGC & IRP1, reverse, intron 3 \\
\hline A51 & CAATAAATGTTGGAAGAGAGTACCC & IRP2, sense, intron 3 \\
\hline A52 & GGCTTCAATAGTCTTCATACCACG & IRP2, reverse, intron 3 \\
\hline
\end{tabular}


centrifugation at $14,500 \mathrm{~g}$ at $4^{\circ} \mathrm{C}$. Protein concentration in the supernatant was determined by $\mathrm{D}_{\mathrm{C}}$ protein assay (BioRad). Then 20 $\mu \mathrm{g}$ of total protein was subjected to Western-blot analysis with polyclonal rabbit IRP1 or IRP2 antibodies raised against recombinant polypeptides, and an HRP-conjugated secondary antibody. Bandshift experiments were performed using $10 \mu \mathrm{g}$ of cytoplasmic extract and a ${ }^{32} \mathrm{P}$-labeled ferritin-H IRE probe as described (Pantopoulos and Hentze 1995).

\section{IRP mRNA analysis}

Total RNA was extracted using the Trizol reagent (Invitrogen), and cDNAs were synthesized from $2.5 \mu \mathrm{g}$ of total RNA using oligo(dT) and Superscript II reverse transcriptase (Invitrogen) according to the manufacturer's instructions. PCR was performed using the PCR master mix (Roche Diagnostic) and the primers listed in Table 1. The PCR products were separated on agarose gels and visualized by ethidium bromide staining. For Northern blotting, a $\beta$-actin probe was used to check for equal loading.

\section{ACKNOWLEDGMENTS}

We are very grateful to B. Leibold (Utah University) for the IRP2 genomic clone; and to F. Stewart, Y. Zhang, and K. Anastassiadis (Technical University of Dresden) for the frt-flanked gene trap $\beta$ Geo construct and help with ET cloning. We thank L. Ortiz Hernandez (Universidad de Navarra) for experimental contributions, K. Brennan for helpful discussions, and the staff of the EMBL Animal Care Facility for their dedicated support. B.G. was the recipient of an EMBO long-term fellowship (ALF199-212). This work was supported by funds from the Gottfried Wilhem Leibniz Prize to M.W.H.

The publication costs of this article were defrayed in part by payment of page charges. This article must therefore be hereby marked "advertisement" in accordance with 18 USC section 1734 solely to indicate this fact.

Received February 20, 2004; accepted March 31, 2004.

\section{REFERENCES}

Bonaldo, P., Chowdhury, K., Stoykova, A., Torres, M., and Gruss, P. 1998. Efficient gene trap screening for novel developmental genes using IRES $\beta$ geo vector and in vitro preselection. Exp. Cell. Res. 244: $125-136$.

Cairo, G. and Pietrangelo, A. 2000. Iron regulatory proteins in pathobiology. Biochem. J. 352: 241-250.

Chowdhury, K., Bonaldo, P., Torres, M., Stoykova, A., and Gruss, P. 1997. Evidence for the stochastic integration of gene trap vectors into the mouse germline. Nucleic Acids Res. 25: 1531-1536.

Danckwardt, S., Neu-Yilik, G., Thermann, R., Frede, U., Hentze, M.W., and Kulozik, A.E. 2002. Abnormally spliced $\beta$-globin mRNAs: A single point mutation generates transcripts sensitive and insensitive to nonsense-mediated mRNA decay. Blood 99: 1811-1816.

Dymecki, S.M. 1996. Flp recombinase promotes site-specific DNA recombination in embryonic stem cells and transgenic mice. Proc. Natl. Acad. Sci. 93: 6191-6196.

Gonzalez-Billault, C., Demandt, E., Wandosell, F., Torres, M., Bonaldo, P., Stoykova, A., Chowdhury, K., Gruss, P., Avila, J., and Sanchez, M.P. 2000. Perinatal lethality of microtubule-associated protein 1B-deficient mice expressing alternative isoforms of the protein at low levels. Mol. Cell. Neurosci. 16: 408-421.

Herrmann, T., van der Hoeven, F., Grone, H.J., Stewart, A.F., Langbein, L., Kaiser, I., Liebisch, G., Gosch, I., Buchkremer, F., Drobnik, W., et al. 2003. Mice with targeted disruption of the fatty acid transport protein 4 (Fatp 4, Slc27a4) gene show features of lethal restrictive dermopathy. J. Cell Biol. 161: 1105-1115.

LaVaute, T., Smith, S., Cooperman, S., Iwai, K., Land, W., MeyronHoltz, E., Drake, S.K., Miller, G., Abu-Asab, M., Tsokos, M., et al. 2001. Targeted deletion of the gene encoding iron regulatory protein-2 causes misregulation of iron metabolism and neurodegenerative disease in mice. Nat. Genet. 27: 209-214.

Meyron-Holtz, E.G., Ghosh, M.C., Iwai, K., LaVaute, T., Brazzolotto, X., Berger, U.V., Land, W., Ollivierre-Wilson, H., Grinberg, A., Love, P., et al. 2004. Genetic ablations of iron regulatory proteins 1 and 2 reveal why iron regulatory protein 2 dominates iron homeostasis. EMBO J. 23: 386-395.

Nagy, A. 2000. Cre recombinase: The universal reagent for genome tailoring. Genesis 26: 99-109.

Orphanides, G. and Reinberg, D. 2002. A unified theory of gene expression. Cell 108: 439-451.

Pantopoulos, K. and Hentze, M.W. 1995. Nitric oxide signaling to iron-regulatory protein: Direct control of ferritin mRNA translation and transferrin receptor mRNA stability in transfected fibroblasts. Proc. Natl. Acad. Sci. 92: 1267-1271.

Pires-daSilva, A., Nayernia, K., Engel, W., Torres, M., Stoykova, A., Chowdhury, K., and Gruss, P. 2001. Mice deficient for spermatid perinuclear RNA-binding protein show neurologic, spermatogenic, and sperm morphological abnormalities. Dev. Biol. 233: 319-328.

Romao, L., Inacio, A., Santos, S., Avila, M., Faustino, P., Pacheco, P., and Lavinha, J. 2000. Nonsense mutations in the human $\beta$-globin gene lead to unexpected levels of cytoplasmic mRNA accumulation. Blood 96: 2895-2901.

Salminen, M., Meyer, B.I., Bober, E., and Gruss, P. 2000. Netrin 1 is required for semicircular canal formation in the mouse inner ear. Development 127: 13-22.

Serafini, T., Colamarino, S.A., Leonardo, E.D., Wang, H., Beddington, R., Skarnes, W.C., and Tessier-Lavigne, M. 1996. Netrin-1 is required for commissural axon guidance in the developing vertebrate nervous system. Cell 87: 1001-1014.

Skarnes, W.C., Auerbach, B.A., and Joyner, A.L. 1992. A gene trap approach in mouse embryonic stem cells: The lacZ reporter is activated by splicing, reflects endogenous gene expression, and is mutagenic in mice. Genes \& Dev. 6: 903-918.

Stanford, W.L., Cohn, J.B., and Cordes, S.P. 2001. Gene trap mutagenesis: Past, present and beyond. Nat. Rev. Genet. 2: 756-768.

Stoykova, A., Chowdhury, K., Bonaldo, P., Torres, M., and Gruss, P. 1998. Gene trap expression and mutational analysis for genes involved in the development of the mammalian nervous system. Dev. Dyn. 212: 198-213.

Zambrowicz, B.P. and Friedrich, G.A. 1998. Comprehensive mammalian genetics: History and future prospects of gene trapping in the mouse. Int. J. Dev. Biol. 42: 1025-1036.

Voss, A.K., Thomas, T., and Gruss, P. 1998a. Efficiency assessment of the gene trap approach. Dev. Dyn. 212: 171-180.

Voss, A.K., Thomas, T., and Gruss, P. 1998b. Compensation for a gene trap mutation in the murine microtubule-associated protein 4 locus by alternative polyadenylation and alternative splicing. Dev. Dyn. 212: 258-266.

Voss, A.K., Gruss, P., and Thomas, T. 2003. The guanine nucleotide exchange factor $\mathrm{C} 3 \mathrm{G}$ is necessary for the formation of focal adhesions and vascular maturation. Development 130: 355-367.

Wiles, M.V., Vauti, F., Otte, J., Fuchtbauer, E.M., Ruiz, P., Fuchtbauer, A., Arnold, H.H., Lehrach, H., Metz, T., von Melchner, H., et al. 2000. Establishment of a gene trap sequence tag library to generate mutant mice from embryonic stem cells. Nat. Genet. 24: 13-14.

Zhang, Y., Muyrers, J.P., Testa, G., and Stewart, A.F. 2000. DNA cloning by homologous recombination in Escherichia coli. Nat. Biotechnol. 18: 1314-1317. 

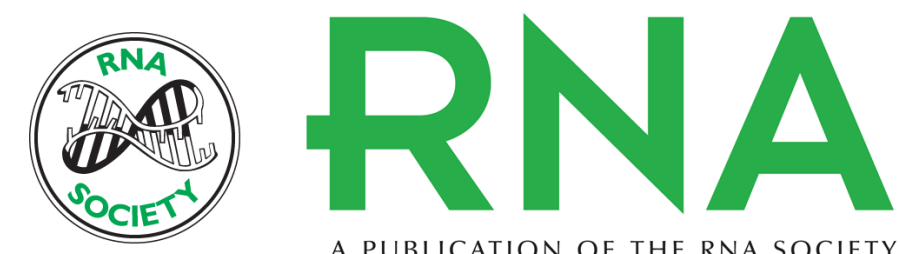

A PUBLICATION OF THE RNA SOCIETY

\section{Targeted mutagenesis of the murine IRP1 and IRP2 genes reveals context-dependent RNA processing differences in vivo}

BRUNO GALY, DUNJA FERRING, MONIKA BENESOVA, et al.

RNA 2004 10: 1019-1025

References This article cites 24 articles, 8 of which can be accessed free at: http://rnajournal.cshlp.org/content/10/7/1019.full.html\#ref-list-1

License

Email Alerting Receive free email alerts when new articles cite this article - sign up in the box at the top Service right corner of the article or click here.

To subscribe to RNA go to:

http://rnajournal.cshlp.org/subscriptions 